\title{
Numbers
}

\author{
Eva Mathews ${ }^{1}$
}

Received: 13 April 2018 / Accepted: 18 April 2018 / Published online: 30 April 2018

(C) Academic Psychiatry 2018

\section{Artist's Statement}

This is a poem I wish I never had the reason to write. It is about my very dear friend, also a psychiatrist, who died by suicide unexpectedly and tragically.

\section{Numbers}

It was $3 \mathrm{am}$, the 19th hour of my shift,

My 28th year,

One loud note of a violin sang into the night

of my call room.

I shifted anxiously in the thin-mattressed twin bed.

Stay calm. Three deep breaths. Talk to someone.

Psychosis can appear in the late 20s in women.

\section{Am I safe?}

Am I paranoid?

Who do I tell? Someone should know.

It's probably fine. I'm just sleep deprived.

Hypnopompic hallucination is number one on the differential. Just in case, though. If I'm not safe to work.

Someone should know.

Five years later, pouring through old emails. A heartbroken detective,

What did I miss?

I see that it was you, of course, I told at 9:39am that February morning,

Finally warm in my own bed,
With an only half-joking subject line entitled "Confession." You were reassuring, logical, distracting.

Present.

I could have done that for you.

For four years we complained about the growing pains Of residency and for nine months we grew larger together Until we had baby boys born six days apart,

Ran emergency rooms and clinics,

Took care of countless patients at three different hospitals Wearing three pagers, one cell phone, two pockets stuffed full of hospital graham crackers.

Before you bought the gun that January day, I could have been distracting, logical, reassuring. Present.

Before you ended your life in your 31st year, 4th month and 11th day,

You could have told me. I could have been with you.

You weren't safe.

Stay calm. Three deep breaths. Talk to someone.

Eva Mathews

Eva.Mathews@fmolhs.org

1 Louisiana State University-Our Lady of the Lake, Baton Rouge, LA, USA 